\title{
臭素成分蛍光 $\mathrm{X}$ 線分析用プラスチック認証標準物質 JSAC 0651-0655 の開発
}

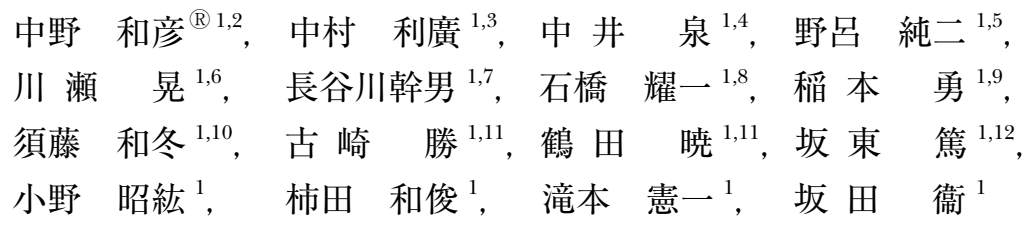

\section{1 緒言}

日本分析化学会は, 2004 年 4 月より有害成分分析用プ ラスチック標準物質作製小委員会を開催し, EU の Restrictions on Hazardous Substance（RoHS）指令 ${ }^{1)}$ に対 応した，有害金属を含むプラスチック標準物質の作製・供 給を行ってきた。これまで分析化学会では, 既にJSAC 0611-0615 $(\mathrm{Pb}, \mathrm{Cd}, \mathrm{Cr} \text { 成分認証：蛍光 X 線分析用 })^{2) 3}$, JSAC 0601, $0602(\mathrm{~Pb}, \mathrm{Cd}, \mathrm{Cr}, \mathrm{Hg} \text { 成分認証: 化学分析用 })^{4)}$, JSAC 0621-0625 ( $\mathrm{Hg}$ 成分認証：蛍光 X 線分析用 $)^{5)}$, 及び JSAC 0631， $0632(\mathrm{~Pb}, \mathrm{Cd}, \mathrm{Cr}, \mathrm{Hg}$ 成分認証：蛍光 X 線 分析用 ${ }^{6)}$ などの標準物質の頒布を行っているが, $\mathrm{Br}$ を含 有したプラスチック標準物質については, 供給を行ってい なかった。

RoHS 指令で規制の対象となっているのは, ポリ臭素化 ビフェニル（PBB）及びポリ臭素化ジフェニルエーテル

\footnotetext{
${ }^{1}$ 社団法人日本分析化学会有害成分分析用プラスチック標準物質 作製小委員会：141-0031 東京都品川区西五反田 1-26-2 五反 田サンハイツ 304

2 大阪市立大学大学院工学研究科 : 558-8585 大阪府大阪市住吉 区杉本 3-3-138

${ }^{3}$ 明治大学理工学部応用化学科 : 214-8571 神奈川県川崎市多摩 区東三田 1-1-1

${ }^{4}$ 東京理科大学理学部応用化学科：162-8601 東京都新宿区神楽 坂 1-3

${ }^{5}$ 株式会社日産アーク研究部：237-0061 神奈川県横須賀市夏島 町 1

${ }^{6}$ エスアイアイ・ナノテクノロジー株式会社：104-0041 東京都 中央区新富 2-15-5 RB 築地ビル

${ }^{7}$ 株式会社住化分析センター千葉事業所：299-0266 千葉県袖ヶ 浦市北袖 9-1

${ }^{8} \mathrm{JFE}$ テクノリサーチ株式会社：210-0855 神奈川県川崎市川崎 区南渡田町 1-1

9 株式会社日鐵テクノリサーチ：293-0011 千葉県富津市新富 20-1

10 株式会社三井化学分析センター：299-0108 千葉県市原市千種 海岸 3

${ }^{11}$ 環境テクノス株式会社：804-0003 福岡県北九州市戸畑区中原 新町 $2-4$

12 株式会社堀場製作所分析センター：601-8510 京都府南区吉祥 院宮の東町 2
}

（PBDE）の臭素系難燃剤の含有量であり, $\mathrm{Br}$ 自体の含有 量を規制しているものではない.しかしながら実際の分析 の現場では，まず蛍光 X 線分析で $\mathrm{Br}$ の含有量のスクリー ニングを行った後，臭素が，あるしきい值を超えた場合に 臭素系難燃郕成分の精密な定量を行うことが一般的となっ ている.このため $\mathrm{Br}$ の含有量を認証した蛍光 X 線分析用 のプラスチック認証標準物質の供給に対する要請が強かっ た.

同委員会ではこのようなニーズにこたえるため, $\mathrm{Br}$ 成 分の濃度を 5 水準としたプラスチック標準物質の開発に着 手した. 2006 年 8 月から候補標準物質の作製を行い，そ れを 19 の試験機関による認証值決定のための共同実験に 供した．報告された分析結果を委員会にて統計処理を行い 審議した後, 認証值を決定して, 2007 年 9 月より臭素成 分蛍光 $\mathrm{X}$ 線分析用プラスチック認証標準物質 JSAC 0651-0655 として供給を開始した. 以下に本標準物質の開 発・認証の経緯について報告する。

\section{2 候補標準物質の作製と均質性の確認}

これまで頒布されているプラスチック標準物質は, プラ スチック粉末に金属顔料等を添加・加熱混合を繰り返して 作製を行う方法が一般的である。これに対し本標準物質で は，液状のプラスチック基材に，有機溶剤で溶解した臭素 試薬を添加・擋拌して標準物質を作製する方法 ${ }^{78)}$ を採用 した。この標準物質調製法は, プラスチック原料に，臭素 試薬の有機溶剂溶液を溶解することで, 含有金属の均質性 が保証された試料が得やすいと考えられる。また，本調製 方法は, EU の BCR プラスチック標準物質（現 European reference Material, ERM 標準物質) のように加熱混合・ 成型などの工程を必要とせず, 試料調製の簡便さも改善し たものである.

\section{$2 \cdot 1$ 原 料}

プラスチック基材には不飽和ポリエステル樹脂（商品 
名：クリアーポリエステル，エポック製）を用いた，不飽 和ポリエステルに添加する $\mathrm{Br}$ 試薬は, テトラブロモビス フェノール A（TBBPA：純度 $98 \%$, 東京化成製）試薬を 用いた， $\mathrm{Br}$ 試薬の溶解には，有機溶媒としてトルエンを 用いた。

\section{$2 \cdot 2$ 候補標準物質の作製}

候補標準物質の調製は環境テクノス(侏において行われ た. 作製した候補標準物質の濃度は, 5 水準であり, 各水 準の目標濃度は, $0 \mathrm{mg} / \mathrm{kg}$ （空試験試料, 空試験用） 100 , $300,600,1000 \mathrm{mg} / \mathrm{kg}$ のように設定した。候補標準の調 製方法を以下に示す.

Step 1：Br 試薬のテトラブロモビスフェノール A を各 水準の含有率に相当する量を秤量し，それぞれトルエンに 溶解した。

Step 2：ポリエステル基材（エポック製，クリアポリエ ステル） $2000 \mathrm{~g}$ をはかり取り，これに前記トルエン溶液 を加え, 容量 $5 \mathrm{~L}$ のポリプロピレン製容器中で 20 分間摚 找した.

Step 3：Step 2 で調製した混合液に硬化㓮（メチルエチ ルイソブチルケトンパーオキサイド, 商品名: パーメック N）を加え，ガラス板上に置いた直径 $40 \mathrm{~mm}$, 媣さ $5 \mathrm{~mm}$ のアルミニウムリングの型に流し込んだ.

Step 4 : 室温で 12 時間放置してディスクを硬化させた 後，ディスクの両面をフライス盤で研削して厚さ $4.00 \pm$ $0.05 \mathrm{~mm}$ に調製した後, バフ研磨により表面仕上げを行 った，候補標準物質は，金属成分含有率高低につき各々 300 個作製し, 仕上げの段階で異物の混入や破損が確認さ れた試料を取り除いて最終製品とした。

\section{$\mathbf{2 \cdot 2}$ 均質性の確認}

作製した各水準のディスクの各群からそれぞれ 20 個の デイスクを無作為に抜き取り, 蛍光 X 線分析法により $\mathrm{Br}$ の含有率について独立 2 回の定量分析を行い, ISO $13528^{9)}$ に準拠した瓶内標準偏差（併行標準偏差） $s_{b}$, 瓶間標準偏 差 $s_{b}$, 及び合成標準偏差 $s_{b+r}$ を算出して標準物質の均質 性を確認した。瓶内標準偏差 $s_{r}$, 瓶間標準偏差 $s_{b}$, 合成 標準偏差 $s_{b+r}$ は以下の式により算出した.

$$
s_{r}{ }^{2}=\frac{1}{2 N} \sum_{1}^{N}\left(x_{i 1}-x_{i 2}\right)^{2}
$$

ここで， $x_{i 1}$ と $x_{i 2}$ はそれぞれ同一試料を併行条件で求 めた二つの定量值. $N$ は試料数である.

合成標準偏差 $s_{b+r}$ は下記の式によって求められる.

$$
\begin{aligned}
& s_{b+r}{ }^{2}=\frac{1}{(N-1)} \sum_{1}^{N}\left(\overline{x_{i}}-\overline{\bar{x}}\right)^{2}+\frac{s_{r}{ }^{2}}{2} \\
& \text { ここで, } \quad \overline{x_{i}}=\left(x_{i 1}+x_{i 2}\right) / 2, \quad \bar{x}=\sum_{1}^{N} \overline{x_{i}} / N .
\end{aligned}
$$

瓶間標準偏差 $s_{b}$ は下記の式によって求められる。

$$
s_{b}{ }^{2}=s_{b+r}{ }^{2}-s_{r}{ }^{2}
$$

式（1）で求められる瓶内標準偏差 $s_{r}$ と式（2）による $s_{b+r}$ に含まれる瓶内標準偏差分はデー夕数が少ない場合は 等しくなるとは限らず, 瓶間標準偏差が小さいと $s_{b}{ }^{2}$ がマ イナスになる場合がある，その場合， $-s_{b}{ }^{2}$ の絶対值 $\left(\left|s_{b}{ }^{2}\right|\right)$ を平方根にした後，マイナスの符号を付けて $s_{b}$ とした

蛍光 X 線分析装置は, 波長分散型蛍光 X 線装置 Rigaku

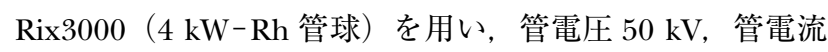
$80 \mathrm{~mA}$ で動作させた．分析線は $\mathrm{BrK} \alpha$ 線である．また，各 水準の定量值は自己キャリブレーションにより算出した.

Table 1 に蛍光 X 線分析による候補標準物質の均質性試 験の結果を示す．その結果，算出した併行標準偏差で 0.09 $\sim 0.20 \%$ ，瓶間標準偏差で $0.07 \sim 0.29 \%$ であり，作製し た候補標準物質は各濃度水準とも十分に均質であると判定 した。

\section{3 認証值決定のための共同実験}

\section{$3 \cdot 1$ 共同実験方法}

認証值の決定方法は，ISO Guide $35^{10)}$ に準拠した共同実 験方式で行った，共同実験では，作製した各水準の試料を 型に流し込んだ順にほほ均等割に採取して共同実験用試料 とし, 参加試験機関に配付した．配付した化学分析方法マ ニュアルに準じて独立 2 回繰り返して分析し含有率を求め た.

共同実験参加試験機関は，過去の共同実験における実績 及び分析業務の専門性などを考虑して標準物質作製委員会 でリストを作成し，参加案内状を送付する形で選定した。 参加した試験機関は次の 19 試験機関（五十音順）である.

イビデンエンジニアリング株環境技術事業部, (財)化学物 質評価研究機構環境技術部，(株環境アシスト分析課，(侏環 境技研技術 1 課，(制クレハ分析センター分析本部高分子試 験室，(株)コベルコ科研環境化学事業部，(株産業公害・医学 研究所八戸分室，(株島津テクノリサーチ品質保証部，(侏住 化分析センター愛媛事業所，中外テクノス(侏関東環境技術 センター, (株東レリサーチセンター有機分析化学研究部, (侏東芝研究開発センター, 東芝ナノアナリシス侏第 1 分析 評価センター，日化テクノサービス侏分析・技術部門日立 分析部，(陎日産アーク研究部，(株ニッテクリサーチ環境技 
Table 1 Homogeneity result of JSAC 0651-0655 measured by XRF analysis

(Unit : $\mathrm{mg} \mathrm{kg}^{-1}$ )

\begin{tabular}{|c|c|c|c|c|c|c|c|c|c|c|}
\hline \multirow[b]{2}{*}{ No. } & \multicolumn{2}{|c|}{ JSAC 0651 (Blank) } & \multicolumn{2}{|c|}{ JSAC 0652} & \multicolumn{2}{|c|}{ JSAC 0653} & \multicolumn{2}{|c|}{ JSAC 0654} & \multicolumn{2}{|c|}{ JSAC 0655} \\
\hline & $1 \mathrm{st}$ & 2 nd & $1 \mathrm{st}$ & 2 nd & $1 \mathrm{st}$ & 2 nd & $1 \mathrm{st}$ & 2 nd & $1 \mathrm{st}$ & 2 nd \\
\hline 1 & -1.01 & -1.12 & 116 & 116 & 305 & 305 & 601 & 602 & 999 & 1001 \\
\hline 2 & -1.42 & -1.19 & 116 & 117 & 304 & 304 & 601 & 602 & 999 & 1000 \\
\hline 3 & -1.19 & -1.22 & 116 & 117 & 305 & 305 & 601 & 601 & 994 & 995 \\
\hline 4 & -1.21 & -1.21 & 117 & 117 & 305 & 304 & 601 & 601 & 997 & 997 \\
\hline 5 & -1.13 & -1.10 & 116 & 117 & 305 & 305 & 601 & 602 & 999 & 999 \\
\hline 6 & -1.33 & -1.14 & 116 & 117 & 305 & 304 & 600 & 601 & 999 & 1001 \\
\hline 7 & -1.15 & -1.12 & 116 & 117 & 305 & 305 & 601 & 603 & 1000 & 1001 \\
\hline 8 & -1.10 & -1.23 & 116 & 117 & 306 & 306 & 600 & 601 & 998 & 1001 \\
\hline 9 & -1.37 & -1.06 & 116 & 116 & 306 & 307 & 601 & 602 & 1002 & 1004 \\
\hline 10 & -1.28 & -1.25 & 117 & 117 & 305 & 306 & 603 & 604 & 992 & 992 \\
\hline 11 & -1.29 & -0.99 & 116 & 117 & 307 & 306 & 600 & 601 & 1002 & 1003 \\
\hline 12 & -1.19 & -1.31 & 117 & 117 & 305 & 307 & 602 & 602 & 998 & 999 \\
\hline 13 & -1.39 & -1.16 & 116 & 116 & 306 & 306 & 601 & 602 & 1001 & 1003 \\
\hline 14 & -1.14 & -1.24 & 116 & 117 & 305 & 306 & 600 & 601 & 1003 & 1004 \\
\hline 15 & -1.29 & -1.19 & 117 & 117 & 306 & 306 & 601 & 602 & 1003 & 1003 \\
\hline 16 & -1.15 & -1.22 & 116 & 117 & 305 & 306 & 601 & 602 & 1001 & 1003 \\
\hline 17 & -1.03 & -1.06 & 116 & 117 & 305 & 306 & 602 & 602 & 1002 & 1003 \\
\hline 18 & -1.07 & -1.16 & 116 & 117 & 305 & 305 & 602 & 602 & 1002 & 1003 \\
\hline 19 & -1.03 & -1.17 & 117 & 117 & 305 & 305 & 602 & 603 & 1002 & 1003 \\
\hline 20 & -1.04 & -1.27 & 116 & 116 & 305 & 305 & 601 & 602 & 1002 & 1001 \\
\hline$N$ & 20 & 20 & 20 & 20 & 20 & 20 & 20 & 20 & 20 & 20 \\
\hline Average & \multicolumn{2}{|c|}{-1.18} & \multicolumn{2}{|c|}{117} & \multicolumn{2}{|c|}{305} & \multicolumn{2}{|c|}{602} & \multicolumn{2}{|c|}{1000} \\
\hline$s_{r}$ & \multicolumn{2}{|c|}{0.11} & \multicolumn{2}{|c|}{0.23} & \multicolumn{2}{|c|}{0.31} & \multicolumn{2}{|c|}{0.69} & \multicolumn{2}{|c|}{0.91} \\
\hline$\left|s_{b}\right|$ & \multicolumn{2}{|c|}{0.01} & \multicolumn{2}{|c|}{0.08} & \multirow{2}{*}{\multicolumn{2}{|c|}{0.61}} & \multicolumn{2}{|c|}{$\begin{array}{l}0.61 \\
0.09\end{array}$} & \multicolumn{2}{|c|}{2.95} \\
\hline$s_{b+r}$ & \multicolumn{2}{|c|}{0.11} & \multirow{2}{*}{\multicolumn{2}{|c|}{$\begin{array}{l}0.24 \\
0.20\end{array}$}} & \multirow{2}{*}{\multicolumn{2}{|c|}{$\begin{array}{l}0.68 \\
0.10\end{array}$}} & \multicolumn{2}{|c|}{$\begin{array}{l}0.92 \\
0.9\end{array}$} & \multicolumn{2}{|c|}{3.10} \\
\hline$R S D_{r}, \%$ & \multicolumn{2}{|c|}{9.1} & & & & & & & & \\
\hline$R S D_{b}, \%$ & & & \multicolumn{2}{|c|}{0.07} & \multicolumn{2}{|c|}{0.20} & & & & \\
\hline$R S D_{b+r}, \%$ & & & & & & & & & & \\
\hline
\end{tabular}

$s_{r}$ : the within-bottle variance, $s_{b}:$ the between-bottle standard deviation, $s_{b+r}:$ the combined standard deviation, RSD : Relative standard deviation

術部, (株)日東分析センター豊橋事業所, (株)三井化学分析セ ンター構造解析研究部, (株)ユニチカ環境技術センター関西 事業所.

\section{$3 \cdot 2$ 分析法}

共同実験は, 参加試験機関が以下の分析方法を選択して 分析を行った。

（i）石英ガラス管燃焼-イオンクロマトグラフィー

（ii）フラスコ燃焼-イオンクロマトグラフィー

（iii）石英ガラス管燃焼-誘導結合プラズマ質量分析法

\section{4 分析結果の評価と認証值の決定}

\section{$4 \cdot 1$ 報告データ}

各試験機関から報告された報告值は, 配布した各水準の ディスクについて，独立した 2 回の分析による結果が, 採 用した分析方法, 試料前処理法などのデータとともに報告 された。

\section{$4 \cdot 2$ 共同実験結果の統計計算}

これまで本委員会では, 標準物質開発関連の共同実験結
果の統計計算について，まず試験機関から報告された 2 デ 一夕から平均值を算出し, この平均值をその機関の報告值 とし, これを用いて各報告值の全機関報告值の平均からの 隔たりを示すロバスト $z$ スコアを計算する.この $z$ スコア の絶対值 $|z|$ が 3 以上の報告值を異常值として棄却した後, 残った報告值から, 改めて平均值, メディアン (中央值), $U_{95 \%}$ (不確かさ), 標準偏差 $(S D)$, 正規化四分位範囲 $(N I Q R)$ などの諸量を計算する，という方法を採用してき た.しかしながら, 今回の共同実験データには一つの問題 があった.

Fig. 1 に, 空試験試料である JSAC 0651 を除く各濃度水 準の $\mathrm{Br}$ の結果を報告值の高さの順で図示したものを示す. 図中の横軸には, 試験所番号-試料前処理方法-分析方法 が示してある。なお，試験所番号は，3・1の共同実験試験 機関の順に対応したものではない.この結果, すべての濃 度水準において，ある特定の試験機関の報告值が常に低值 を示しており，特に濃度水準が高い JSAC 0654（濃度水準 $600 \mathrm{mg} / \mathrm{kg}$ ）及び JSAC 0655 （濃度水準 $1000 \mathrm{mg} / \mathrm{kg}$ ）に ついてはこの傾向が顕著であった。しかもそれは分析法と は関連はないので, 試料前処理の不十分さに起因する疑い 

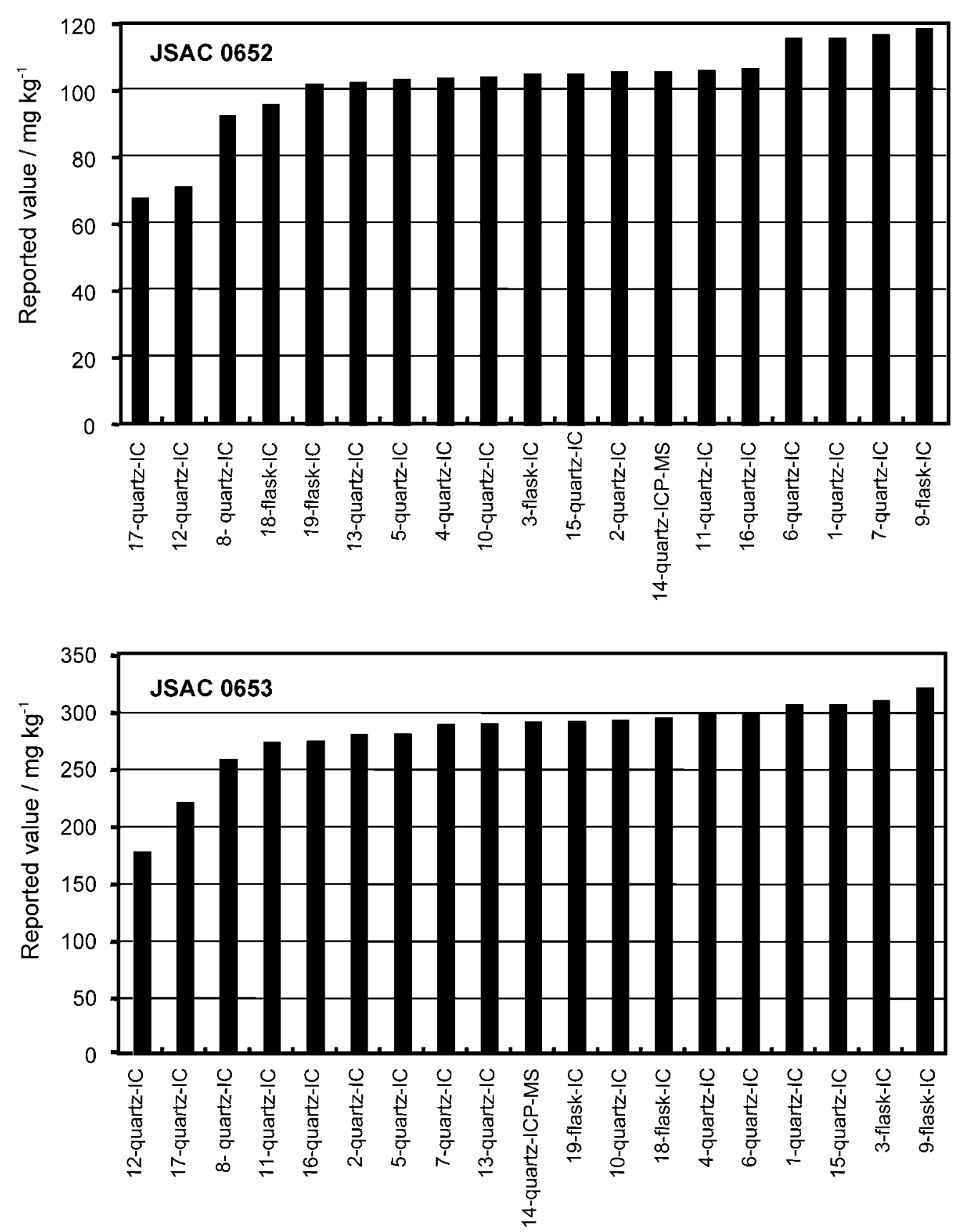

Fig. 1

が大きい。このような偏りが明らかな状態で z スコアを計 算し，異常值を裹却する方法が妥当であるかどうか疑問が 残った。

そこで本委員会で検討の結果, 認証值及び諸量の計算に は，平均值に変えてこのような偏りの影響の少ないメディ アン（中央值）を採用することにした，ただし，特に低值 を示した $2 つ の$ 試験機関の報告値を棄却した後の分析值か らメディアンを求めた，それらの計算結果を Table 2 に示 す.
$4 \cdot 3$ 空試験試料（JSAC 0651 ; 空試験用）の認証値

本委員会に扔いて, 空試験試料（濃度水準 $0 \mathrm{mg} / \mathrm{kg}$, 空 試験用）の認証值の取り扱いについても議論がなされた. 各試験機関の空試験試料の報告值は，5つの試験機関が分 析值を報告し，その他 14 の試験機関が分析值 0 , もしく は検出下限以下というものであった（Fig. 2)。しかしな がら，分析值を報告した 5 試験機関についても，その報告 值が $2.6 \sim 17 \mathrm{mg} / \mathrm{kg}$ とばらつきの大きいものであり，こ れらの報告值から空試験試料の認証值を算出することはで きないものと判断した。そこで, 1 つの試験機関が代表し て空試験試料の測定を繰り返し行い，標準偏差の 10 倍な 

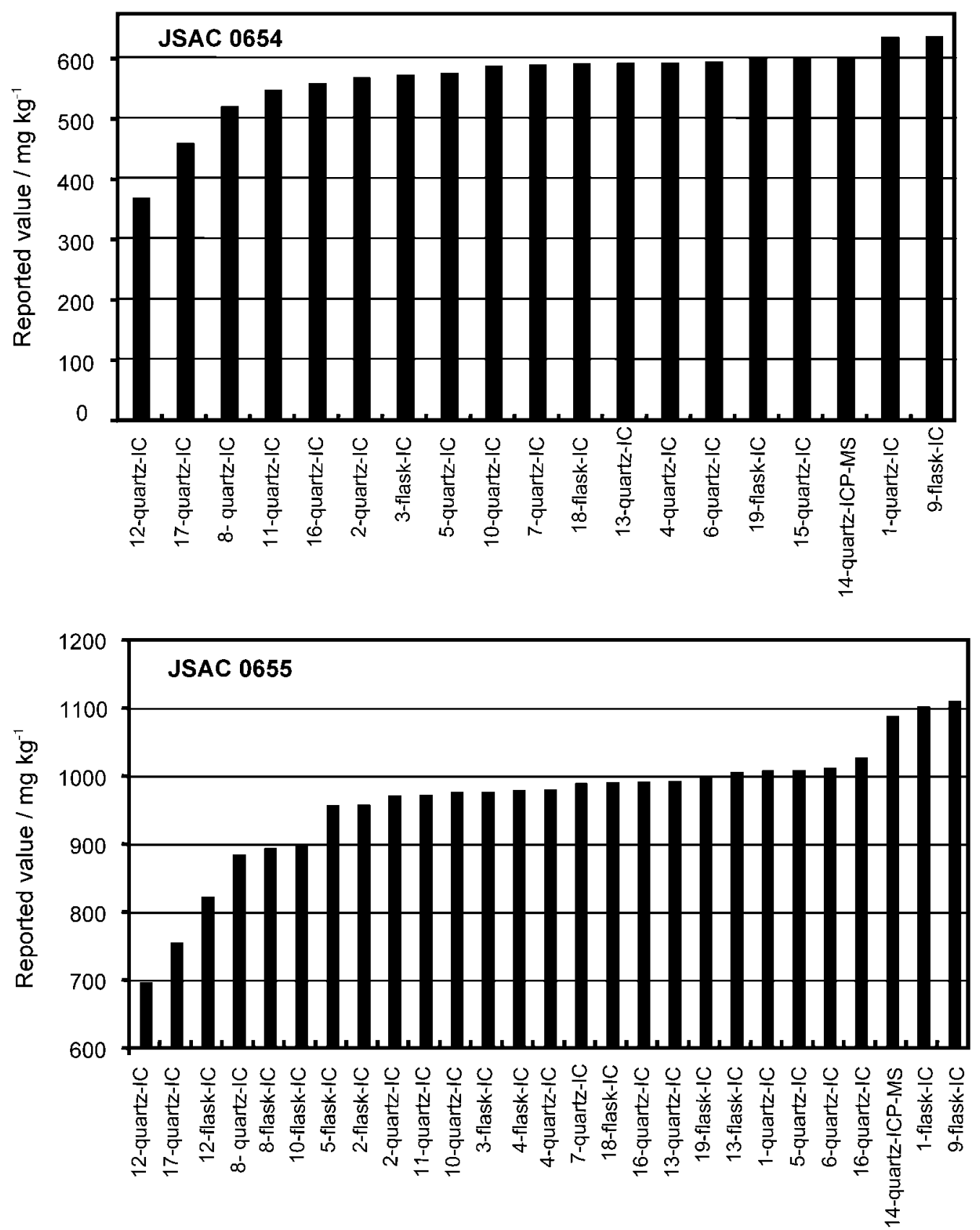

Fig. 1 Bar graphs of reported results from 19 laboratories for $\mathrm{Br}$ in JSAC 0652-0655 quartz : quartz combustion method, flask : flask combustion method, IC : Ion chromatography, ICP-MS : Inductively coupled plasma mass spectrometry

どから定量下限を算出した結果， $\mathrm{Br}$ の定量下限は約 $1 \mathrm{mg} / \mathrm{kg}$ であった。 これらの結果を本委員会で検討した結 果, 認証書には "<1 mg/kg "とし,「空試験試料（空試験 用試料）のバックグラウンド信号の標準偏差の 10 倍から 求めた」と認証書に追記することとした。

\section{$4 \cdot 4$ 認証値の決定}

Table 2 のメディアンと $U_{95 \%}$ を用い, 有効数字を考慮 したMedian $\pm U_{95 \%}$ を標準物質の認証值とし，臭素無添加
の空試験用試料に認証值は "1 未満 " として表示した。決 定した認証值を Table 3 に示す.

$$
5 \text { 結 言 }
$$

日本分析化学会は，RoHS 指令に対応した Br 成分を認 証した蛍光 $\mathrm{X}$ 線分析用プラスチック標準物質 JSAC 0651-0655の開発・認証を行った．RoHS 指令が制定され る以前, $\mathrm{Br}$ は臭素系難燃剂としてプラスチック中にごく 一般的に添加されてきた成分であり，プラスチック製品の 
Table 2 Statistical analysis of the analytical results of Br in JSAC 0651-0655

(Unit : $\mathrm{mg} \mathrm{kg}^{-1}$ )

\begin{tabular}{rcccccrrrrr}
\hline Sample & $N$ & $|z| \geqq 3$ & Average & Median & $U_{95 \%}$ & NIQR & $U_{95 \%} C V \%$ & $C V \%_{\text {clas }}$ & $C V \%_{\text {rob }}$ & $S D$ \\
\hline JSAC 0651 & 14 & 0 & 0.00 & 0.00 & 0.00 & 0.00 & 125.3 & 119.4 & 209.3 & 0.1 \\
JSAC 0652 & 17 & 8 & 106.7 & 105.80 & 3.59 & 2.37 & 2.11 & 3.80 & 3.74 & 0.4 \\
JSAC 0653 & 17 & 2 & 292.6 & 292.6 & 7.93 & 14.04 & 2.04 & 3.53 & 2.93 & 1.7 \\
JSAC 0654 & 17 & 2 & 589.6 & 595.0 & 14.71 & 19.65 & 1.82 & 3.28 & 3.22 & 4.0 \\
JSAC 0655 & 17 & 5 & 993.1 & 992.9 & 23.33 & 27.22 & 2.57 & 4.63 & 3.53 & 11.3 \\
\hline
\end{tabular}

$N$ : number of data accepted, $U_{95 \%}:$ uncertainty of average from accepted data, $S D:$ standard deviation, NIOR: normalized interquartile range by robust method, $U_{95 \%} C V \%$ : percentage of $U_{95 \%} /$ Average, $C V \%_{\text {clas }}$ : percentage of $S D /$ Average, $C V \%_{\text {rob }}$ : percentage of NIQR/Median

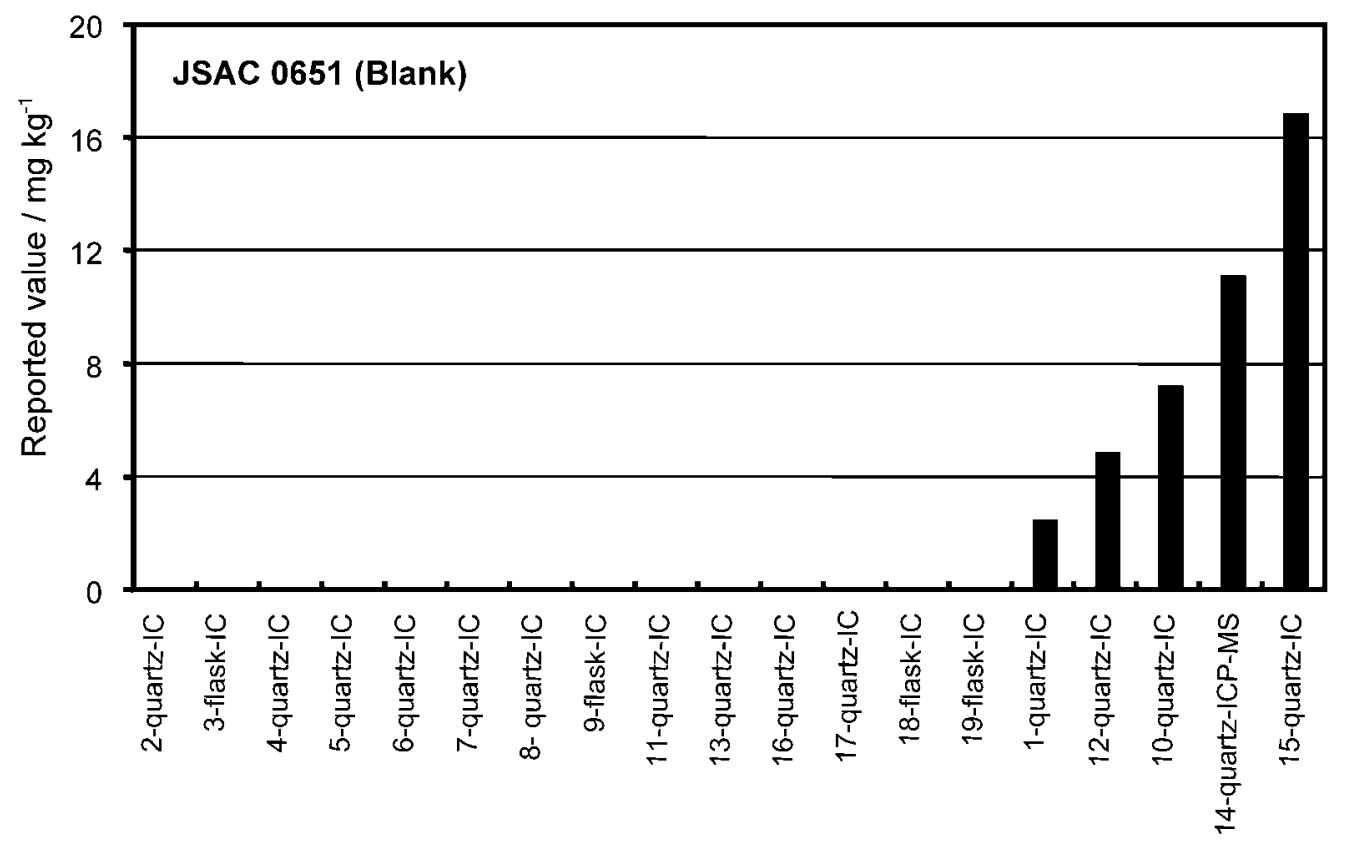

Fig. 2 Bar graph of reported results from 19 laboratories for $\mathrm{Br}$ in JSAC 0651 (blank) quartz : quartz combustion method, flask : flask combustion method, IC : Ion chromatography, ICP-MS : Inductively coupled plasma mass spectrometry

Table 3 Certified values of $\mathrm{Br}$ in JSAC 0651-0655

\begin{tabular}{cccc}
\hline Sample & $\begin{array}{c}\text { No. of data } \\
\text { accepted } / N\end{array}$ & $\begin{array}{c}\text { Certifeid value/ } \\
\mathrm{mg} \mathrm{kg}^{-1}\end{array}$ & $S D / \mathrm{mg} \mathrm{kg}^{-1}$ \\
\hline JSAC 0651 & 14 & $>1$ & - \\
JSAC 0652 & 17 & $105.8 \pm 3.6$ & 6.9 \\
JSAC 0653 & 17 & $292.6 \pm 7.9$ & 15 \\
JSAC 0654 & 17 & $595 \pm 15$ & 28 \\
JSAC 0655 & 24 & $993 \pm 23$ & 55 \\
\hline
\end{tabular}

リサイクル・リユースの過程で最も混入しやすい成分の一 つとなっている. 実際の分析現場において, 蛍光 X 線分 析による臭素のスクリーニングが一般的となっている今日 では, $\mathrm{Br}$ の含有量を認証した本標準物質は有効な役割を 果たすはずである.

本標準物質の開発にご協力いただいた共同実験参加機関に対し
て甚大なる敬意を表する.

\section{文献}

1) Directive 2002/95/EC (2003).

2) K. Nakano, K. Tsuji, M. Kozaki, K. Kakita, A. Ono, T. Nakamura : Adv. in X-Ray Anal., 49, 280 (2006).

3) 中野和彦, 中村利廣, 中井泉, 川瀬 晃, 今井 眞, 長谷川幹男, 石橋耀一, 稲本 勇, 須藤和冬, 古崎 勝, 鶴田 暁, 本間 寿, 小野昭紘, 柿田和 俊, 坂田 衞: 分析化学 (Bunseki Kagaku), 55, 501 (2006).

4) 中野和彦, 中村利廣, 中井泉, 川瀬 晃, 今井 眞, 長谷川幹男, 石橋耀一, 稲本 勇, 須藤和冬, 古崎 勝, 鶴田 暁, 小野昭紘, 柿田和俊, 坂田 衞: 分析化学 (Bunseki Kagaku), 55, 799 (2006).

5) K. Nakano, T. Nakamura, I. Nakai, A. Kawase, M. Imai, M. Hasegawa, Y. Ishibashi, I. Inamoto, K. Sudou, M. Kozaki, S. Turuta, A. Ono, K. Kakita, M. 
Sakata : Anal. Sci., 22, 1265 (2006).

6) 中野和彦, 中村利廣, 中井 泉, 川瀬 晃, 今井 眞, 長谷川幹男, 石橋耀一, 稲本 勇, 須藤和冬, 古崎 勝, 鶴田 暁, 坂東 篤, 小野昭紘, 柿田和 俊, 滝本憲一, 坂田 衞: 分析化学 (Bunseki Kagaku), 56, 363 (2007).

7) K. Nakano, T. Nakamura : X-Ray Spectrom., 32, 452
(2003).

8) 中野和彦, 本村和子, 松野京子, 中村利廣 : X 線分 析の進歩, 35, 101 (2004).

9) ISO 13528 : 2005 "Statistical methods for use in proficiency testing by interlabolatory comparisons".

10) ISO Guide 35 ; 2006 "Certification of Reference materials -General and statistical princples”.

\title{
Development of Certified Reference Materials, Plastics (JSAC 0651-0655) for Determination of Bromine Using X-Ray Fluorescence Analysis
}

\author{
Kazuhiko NAKANO ${ }^{1}$, Toshihiro NAKAmura ${ }^{1}$, Izumi NAKAI ${ }^{1}$, Junji Noro ${ }^{1}$, \\ Akira KaWASE $^{1}$, Mikio HasegaWA ${ }^{1}$, Yohichi Ishibashi ${ }^{1}$, Isamu Inamoto ${ }^{1}$, \\ Kazuhuyu Sudou ${ }^{1}$, Masaru KozAKI ${ }^{1}$, Satoshi Turuta ${ }^{1}$, Atsushi Bando ${ }^{1}$, \\ Akihiro ONO $^{1}$, Kazutoshi KAKITA ${ }^{1}$, Kenichi TAKImOTO ${ }^{1}$ and Mamoru SAKATA ${ }^{1}$
}

${ }^{1}$ The Committee for the Plastic CRMs for Hazardous Metals in The Japan Society for Analytical Chemistry, 1-26-2, Nishigotanda, Shinagawa-ku, Tokyo 141-0031

(Received 30 August 2007, Accepted 6 March 2008)

The Japan Society for Analytical Chemistry has developed plastic certified reference materials (CRMs) for the X-ray fluorescent analysis of bromine in plastics. Disk samples were prepared by filling $\mathrm{Al}$-cylindrical molds with raw material liquid of polyester resin mixed with a hardener and bromine compounds. Thus, 300 candidate reference materials of JSAC 0651-0655 were obtained. Both surfaces on prepared disks obtained after $12 \mathrm{~h}$ of hardening at room temperature were ground and polished by a milling machine at $4.00 \pm 0.05 \mathrm{~mm}$ thick. The homogeneity of prepared disks was shown to be excellent. The certified values were evaluated by a statistical analysis of the results of an interlaboratory comparison study. An interlaboratory comparison study was performed by participants from 19 laboratories. The medians of the results were applied for the certified values in stead of the averages as before, because there was some lower bias in reports from some laboratories.

Keywords : plastics ; polyester resin ; certified reference materials ; XRF analysis ; interlaboratory comparison study; bromine. 